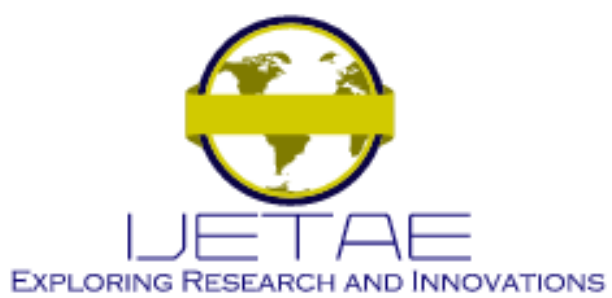

International Journal of Emerging Technology and Advanced Engineering

Website: www.ijetae.com (E-ISSN 2250-2459, Scopus Indexed, ISO 9001:2008 Certified Journal, Volume 11, Issue 08, August 2021)

Manuscript Received: 05 July 2021, Received in Revised form: 07 August 2021, Accepted: 15 August 2021～DOI: 10.46338/ijetae0821_09

\title{
The Impact of Online Learning During theCovid-19 Pandemic (Case Study: Private University in Jakarta)
}

\author{
Kristina Hendryka ${ }^{1}$, Richardo Christjia ${ }^{2}$, William Alex Chandra ${ }^{3}$, Dennis Pedra ${ }^{4}$, Mark Bryan Putera Horeb Timbuleng ${ }^{5}$, \\ Kevin Vincentius ${ }^{6}$, Tanty Oktavia ${ }^{7}$, Ford Lumban Gaol ${ }^{8}$, Takaaki Hosoda ${ }^{9}$ \\ 1,2,3,4,5,7, Information Systems Department, School of Information Systems, Bina Nusantara University, Jakarta, Indonesia 11530 \\ ${ }^{8}$ Computer Science Department Binus Graduate Program - Doctor of Computer Science, Bina Nusantara University, Jakarta, \\ Indonesia 11530 \\ ${ }^{9}$ Decision Science Department, Advanced Institute of Industrial Technology Tokyo, Japan
}

\begin{abstract}
The virus Covid-19 has caused enough trouble for the whole world for nearly a year, ever since it first emerged in Wuhan, China, in December 2019. All areas of life are affected in a way or more, especially the education sector. Learning process shifting to be online at home, and it is now commonly referred to as online learning. Despite the now regulated way of learning, debates regarding the effectiveness of online learning are widely circulated. Thus, the purpose of this study is to investigate the effectiveness of online learning, and whether it has positively or negatively impacted the students in any way. The result shows that online learning really has significantly positively impacted students' performance. Their learning achievement, self-efficacy, as well as learning motivation have shown to be greatly affected by this way of learning. The sources of impacts come from the way the learning materials are delivered, how the class is held, and the educators themselves.
\end{abstract}

Keywords- Online learning, Covid-19, students' performance, learning achievement, self-efficacy

\section{INTRODUCTION}

Education is essential for the younger generation because for the world we live in today [1], education seems to be their weapon, however, the teaching and learning process is now limited by the Covid-19 pandemic outbreak. Not only Indonesia, but almost all countries in the world have also been hit by the coronavirus outbreak, a group of viruses htcan cause respiratory infections in humans. Last year, on January 30, 2020, Covid-19 was declared as a Public Health Emergency of International Concern (PHEIC) or a Public Health Emergency that Concerned the World (KKMMD). By 30 January 2021, this global pandemic outbreak has been going on for a year.

The number of COVID-19 cases every day is still increasing. To date, 219 countries in the world have been hit by the virus, with $25,792,834$ active cases with a death rate of 2,132,074 people.
In Indonesia, the COVID-19 pandemic has threatened various sectors and fields in terms of the economy, companies, jobs, and most importantly education. The learning process carried out by students and students in Indonesia has been plagued by COVID-19, where now people are implementing Large-Scale Social Restrictions so, they are forced to undergo their education through the online system that is implemented remotely. This learning method is supported by several applications such as Zoom, Google Classroom, and Microsoft Teams that allow lecturers ad students to interact together even though everyone is in their own home.

During the Coronavirus pandemic, all students of all levels, from elementary to university level, must change the learning mechanism. From what initially took place faceto- face, the learning system has been changed to onlinebased learning. This shifting must be implemented to reduce the risk of transmission of the Coronavirus (Covid19). However, it cannot be denied that the coronavirus pandemic (COVID-19) has a significant effect on the quality of education in Indonesia. The process of implementing Online Learning which is currently being applied is a challenge for students and lecturers alike.

In a research entitled Student Stress Due to Online Learning During the Covid Pandemic carried out by Afnijar Wahyu and Rostome Hermayerni Simanullang [2], a study was conducted to determine the impact of online learning methods on students. From the 47 respondents they examined, 23 of them admitted to feeling light stress, 20 experienced moderate stress, while the remaining 4 experienced severe stress. 


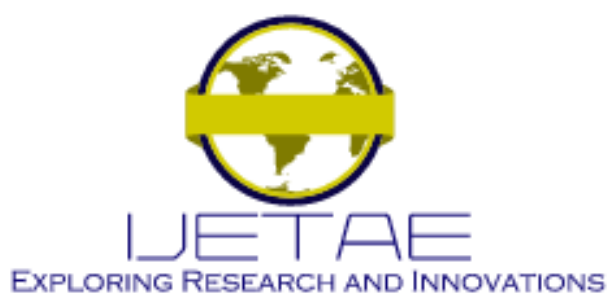

International Journal of Emerging Technology and Advanced Engineering Website: www.ijetae.com (E-ISSN 2250-2459, Scopus Indexed, ISO 9001:2008 Certified Journal, Volume 11, Issue 08, August 2021)

Table 1

Frequency Distribution Of Student Stress Due To Online Learning During The Covid Pandemic 19 [2]

\begin{tabular}{|c|c|c|}
\hline Stress Level & Frequency ( $f$ ) & Percentage $(\mathscr{x})$ \\
\hline Mild stress & 23 & 48.9 \\
\hline Moderate stress & 20 & 42,6 \\
\hline Heavy Stress & 4 & 8.5 \\
\hline
\end{tabular}

Based on a survey conducted by UNICEF in early June 2020 of 4,016 respondents aged 14-24 from 34 provinces in Indonesia, 69\% felt bored learning from home. During the learning process from home, respondents experienced two challenges during online learning, namely $35 \%$ admitted that they had difficulty accessing the internet and $38 \%$ lacked lecturer guidance.

In fact, the Ministry of Education and Culture (Kemendikbud) has stated that online learning standards cannot be equated with face-to-face learning standards in schools. Curriculum targets during the COVID-19 pandemic must also be distinguished from learning activities in normalconditions. The National Consultant for Education in Emergency Situations UNICEF-RDI, also stated the same thing. Based on his assessment, he stated that the quality of Indonesian education had decreased since the COVID-19 pandemic.

Deputy Secretary-General of the Federation of Indonesian Lecturers' Unions (FSGI), Satriwan Salim [3], also stated that the online learning method applied during the COVID-19 pandemic reduced the maximum implementation of the learning process undertaken by lecturers and students. Limitations in the mastery of technology to the delivery of material are now common obstacles.

\section{THEORY}

\section{A. Theoretical Framework}

The discomfort in the learning process will certainly have a significant effect on students. From this research, we wanted to prove the impact that online learning has on:

1. Learning achievement

2. Self-Efficacy

3. Learning motivation

Student learning achievement can be described as the level of student achievement in terms of knowledge, skills, and learning experiences formulated by the learning objectives for the school curriculum [4].
The level of learning achievement of a student is determined by several factors [5], but the most influencing factor, of course, is the condition of the student himself during the teaching and learning process.

Self-efficacy is an individual's perception of his ability to produce results and achieve the desired performance. Self- efficacy is oriented towards specific situations and individuals (students) who make decisions based on several goals. Self-efficacy is also defined as the belief to get the desired results, where this belief is associated with the student's ability to learn the material and achieve the required goals. Students who have a high level of selfefficacy will get high learning achievement.

Theoretically, learning motivation is something that moves and engages students in the learning process [6]. Motivation to learn can also be interpreted as a desire to learn and has a significant effect on learning achievement. Motivation to learn has a function and effect on students, one of which is to determine what actions must be done in harmony to achieve goals, by setting aside actions that are not useful for these goals. Students who have high learning motivation, of course, have a high level of self-efficacy.

Effective learning conditions are an important aspect of success in the learning process [7]. Effective learning conditions must be conducive and can support the smoothness and continuity of the learning process. The implementation of learning activities must have a lively learning interaction between lecturers and students, as well as make use of appropriate learning resources. Lecturers must be able to create a pleasant learning atmosphere and motivate students to actively participate in the learning process. Thus, the learning environment can be said to be conducive.

The learning environment means everything that is related to the place and process of learning [8], where the environment is controlled by the lecturer. Boredom, difficulty, weak self- estimation, and the emergence of a negative view of students towards learning, are the results that arise from the lack of attention paid by lecturers to the learning environment. As a result, the achievement of the mission and learning objectives becomes a dilemma. For learning to be conducive, a lecturer must have knowledge about students, expect students' previous experiences and develop them optimally during the learning process.

Learning material has a major effect on student learning motivation, where if the learning material presented is easy to understand and in accordance with student interests, of course learning motivation will soar. 


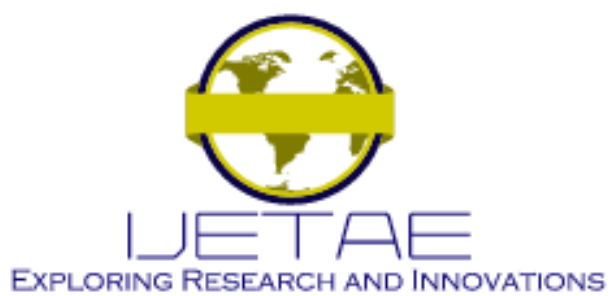

International Journal of Emerging Technology and Advanced Engineering

Website: www.ijetae.com (E-ISSN 2250-2459, Scopus Indexed, ISO 9001:2008 Certified Journal, Volume 11, Issue 08, August 2021)

Conversely, if the learning material does not match the student's interest or is considered too difficult to understand, the interest and motivation to learn will be very low. Success or not someone in learning is due to several factors that affect the achievement of learning outcomes. To increase student interest in learning, the teaching methods and materials used must be precise, efficient, and effective, namely by carrying out variation skills in conveying material.

A student's learning achievement cannot be separated from or is even closely tied to the environmental conditions in which they carry out the learning process, whether positive and negative conditions. This is proved by the research conducted by Nova Asvio, Arpinus, Suharmon [9] who explained the results of research related to GPA, there is a beneficial correlation in improving student achievement which is influenced by the learning environment [9]. In addition, there is a beneficial and significant relationship between learning creativity, the use of power points as a learning medium, both directly and indirectly, on learning outcomes [10].

\section{B. Framework of Thinking}

With the theory outlined above, this study will focus to explore the effects of online learning on students. The level of learning motivation, self-efficacy, and the learning achievement of a student will be closely related to how learning activities are carried out during Online Learning, the learning material presented, and the teaching methods of the lecturer.

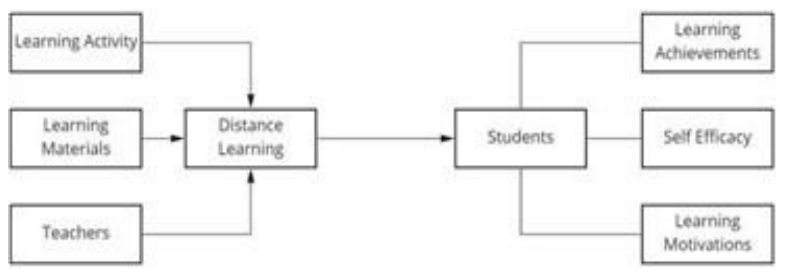

Figure 1 Research Framework

In conducting this research, this study involves the learner's point of view and what influences online learning because from the student's side, we can know what the expectation from their sides. The variable from student will be divided into some indicators, which are learning achievement, self-efficacy and learning motivation. Learning achievement is the ups and downs of learning outcomes during online learning. Then there is self-efficacy where students determine the learning targets they want to get.
Where self-efficacy must be motivated to learn to achieve the desired target, the greater the motivation obtained, the students are closer to the target to be achieved. The factor affecting students is the online learning method currently being implemented due to the COVID-19 pandemic. In the online learning process, there are things that influence it, namely learning activities, learning materials and lecturers (educators). Learning activities and learning materials are one of the factors because if in the teaching and learning process in the delivery of material and students actively ask and answer questions about the material provided, learning activities can be said to be active. Online learning activities are very difficult where lecturers can use the applications / technology used so that there are no obstacles when learning takes place, and the delivery of material must be effective so that students can easily understand it. It can be said that if students want to get the target they want to achieve, the lecturers must be able to convey their teaching well in online learning.

\section{METHOD}

\section{A. Type of Research}

In conducting this research, this study used quantitative methods, a way of research that emphasizes its analysis of numerical data which will then be processed using statistical methods. The data collection technique used in this research is a questionnaire method. The questionnaire will be carried out in a closed manner, in which the questionnaire has already been provided with answers, so the respondent only needs to choose and answer directly. The statements in the questionnaire will be described using a Likert scale because with this scale the respondents can choose based on their level of agreement with the statements by selecting one of the available options.

\section{B. Population and Samples}

Population is a collection of individuals or objects which have common characteristics. Meanwhile, the sample is a part or representative of the population studied.

In this study, the population and sample used were Indonesian students who had carried out online learning during the Covid-19 pandemic. It is because this study focuses on finding out whether there is an impact of online learning caused by the Covid-19 pandemic on the learning success ofstudents and students. 


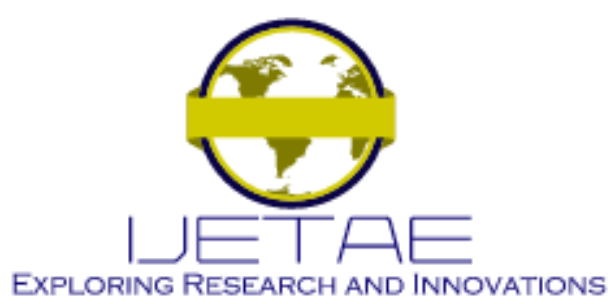

International Journal of Emerging Technology and Advanced Engineering Website: www.ijetae.com (E-ISSN 2250-2459, Scopus Indexed, ISO 9001:2008 Certified Journal, Volume 11, Issue 08, August 2021)

From the sample obtained, the researcher can find out the impact of online learning on learning achievement, selfefficacy, and learning motivation of students. Therefore, the number of samples used in this study were 37 students in that comes from 20 private university in Jakarta, Indonesia.

\section{Descriptive}

The questionnaire that we distributed to analyze the impact of online learning during the Covid-19pandemic on students can be filled in and is aimed to be filled by students from junior high school, high school, and college students. In this study, this used 2 variables, namely Online Learning and Student where the independent variable is Online Learning (X) and the dependent variable is Student's performance $(\mathrm{Y})$.

This is because Online Learning affects Student's performance. The $\mathrm{X}$ variables consist of three indicators which are, learning activities, learning material, and online tutor. As for the $\mathrm{Y}$ variables consist of learning achievement, self-efficacy, and learning motivation.

\section{RESULTS}

Before this research analyze the finding, there are some preliminary tests to check the qualification of data, such as readability test, validity and reliability data.

\section{A. Readability Test}

In the first step, we have conducted a readability test of the questionnaire that will be distributed to determine the respondent's level of understanding of each question. Based on the test, it shows that all the questions have fulfilled the 5 aspects of assessments that we have determined, namely the question or statements given can be understood clearly, the choice of answers can be understand easily and clearly, the language used is easy to understand, the instructions and answer commands are clear and easy to understand, and the questions can be answered easily.

\section{B. Respondents Criteria}

From the questionnaires that we have distributed, we obtained a sample of 37 students from 20 university in Jakarta who had carried out online learning during Covid19 pandemic. The following tables are the details of the age (Fig. 2), gender (Fig. 3) of the respondents' description. The range of gender is different because some on respondents are late for their education, or they study while working.

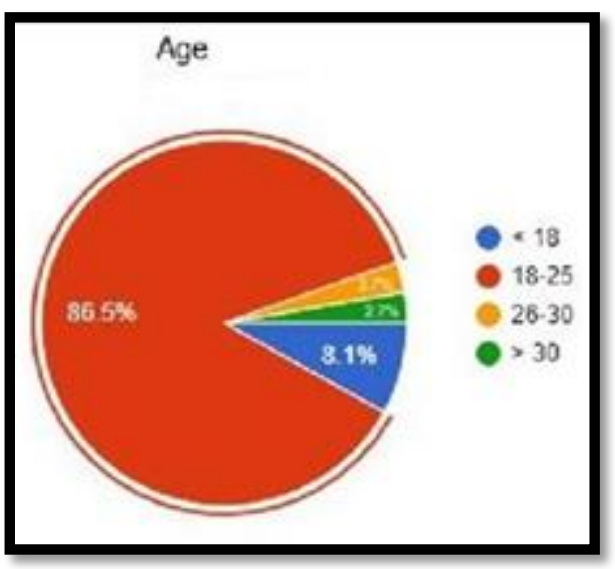

Figure 2 Respondents by Age

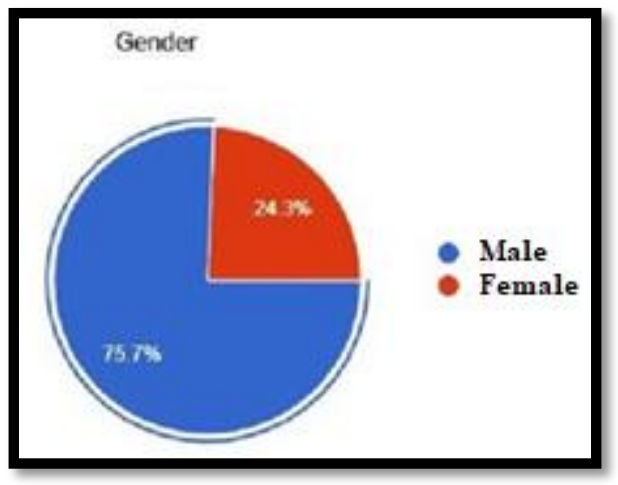

Figure 3 Respondents by Gender

\section{Validity Test}

Validity test is used to test the accuracy and correctness of an instrument as a measuring tool for research variables. In this research, we conducted the validity test of the $\mathrm{X}$ and $\mathrm{Y}$ variables using the SPSS program. The test technique that we use is Pearson Bivariate correlation with the significance value of 0.005 for 37 respondents. Therefore, the results of $\mathrm{r}$-Table value would be 0.325 .

\section{a) Variable $X$}

Based on the validity test that has been conducted on variable $X$, its results show that there are 3 invalid statements which are KP2, PO3, and PO4. KP2 has an rCount value of $0.234, \mathrm{PO} 3$ has an r-Count value of 0.269 , and PO4 has an r-Count value of 0.119. The three values of $\mathrm{r}$-Counts have a smaller value than the r-Table which is 0 . 325.Therefore, it can be concluded that statements with code $\mathrm{KP} 2, \mathrm{PO} 3$ and PO4 are invalid. 


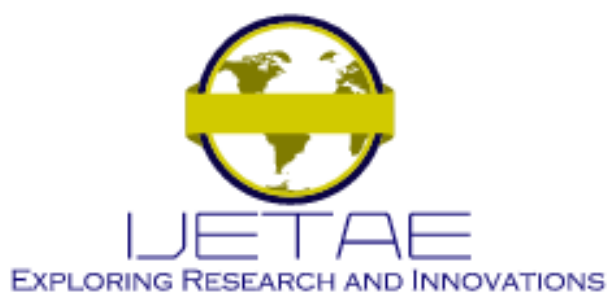

International Journal of Emerging Technology and Advanced Engineering

Website: www.ijetae.com (E-ISSN 2250-2459, Scopus Indexed, ISO 9001:2008 Certified Journal, Volume 11, Issue 08, August 2021)

\section{b) Variable $Y$}

Based on the validity test that has been conducted on variable $\mathrm{Y}$, its results show that there are 1 invalid statement which is MB1. MB1 has an $\mathrm{r}$ Count value of 0,396 . Therefore, it can be concluded that statements with code MB1 is invalid.

\section{Reliability Test}

Reliability test is conducted to see the suitability of the values in a questionnaire carried out by respondents. By taking data only for valid instruments, the reliability coefficients are obtained as in the following table.

Tabel 1

Reliability Statistics

\begin{tabular}{|c|c|}
\hline $\begin{array}{c}\text { Cronbach' } \\
\text { s Alpha }\end{array}$ & N of Items \\
\hline 0.909 & 26 \\
\hline
\end{tabular}

Based on the reliability test results on Table 1, the Cronbach's Alpha value is 0.909 which is greater than the minimum value of Cronbach's Alpha which is 0.6. Therefore, it can be concluded that the research instruments used to measure both variables $\mathrm{X}$ and $\mathrm{Y}$ are reliable.

\section{E. Hypothesis Test}

a) T-Test

T-Test is one of the statistics used to test the truth or falsity of the hypothesis which states that between two samples means that is taken randomly from the same population. In this research we conducted a T-test to test the significance between variable $\mathrm{X}$ and $\mathrm{Y}$.

- Hypothesis:

$$
\begin{gathered}
\mathrm{H}_{0}: \beta_{0}=0 \text {; } \begin{array}{c}
\text { there is no positive impact of } \\
\text { online learning on students' } \\
\text { performance }
\end{array} \\
\mathrm{H}_{1}: \beta_{0} \neq 0 \text {; } \begin{array}{c}
\text { there is positive impact of } \\
\text { online learning on students' } \\
\text { performance }
\end{array}
\end{gathered}
$$

From the fact above, most respondents who filled out the questionnaire were in the age range of $18-25$ years old. And most of the respondents were also male with the total of 28 people.

\section{Criteria:}

Reject $\mathrm{H} 0$ and accept H1, if:

- $\quad$ Significance value $<\alpha=0.05$
- $\quad$ t-Count $>$ t Table

- t Table value:

$$
\begin{aligned}
\mathrm{t} \text { table }= & \mathrm{t} \\
& (\mathrm{a} / 2: \mathrm{n}-\mathrm{k}-1) \\
& =\mathrm{t}(0.05 / 2: 35-2-1) \\
& =\mathrm{t}(0.025: 32) \\
& =2,03693
\end{aligned}
$$

Tabel 2

Coefficients

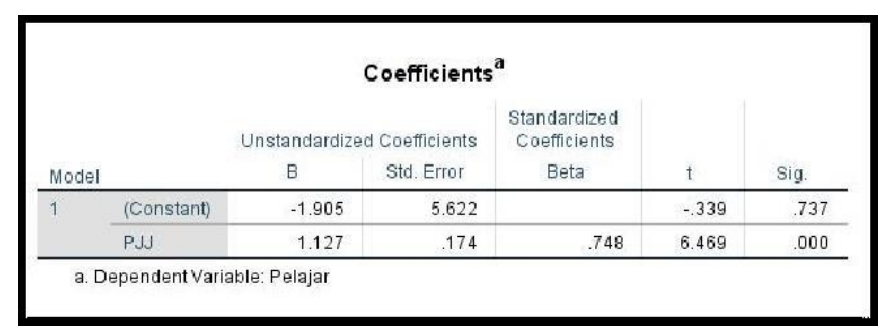

Based on the data in Table 2, it is obtained t Count of 6.469 and a significance value of 0.000 . From the results of these calculations, the value of $t$ Count $>t$ Table is $6.469>2.03693$ and the significance value <the specified probability level $(0.000<0.05)$. So, it can be concluded that $\mathrm{HO}$ is rejected and $\mathrm{H} 1$ is accepted, which implies that Online Learning has a significant positive effect on students' performance. So, if an educational institution wants to implement the Online Learning method, the institution must consider the learning activities that will be carried out, the method of delivering effective learning materials, and online teaching. This is done to increase learning achievement, self-efficacy, and learning motivation from students.

\section{b) F-Test}

F- Test or Anova is used to see how all the independent variables simultaneously influence the dependent variable. The F- Test can also be used to test whether the regression model made is significant or non-significant. In this researchwe conducted an F-Test on variables $\mathrm{X}$ and $\mathrm{Y}$.

- Hypothesis:

$$
\begin{gathered}
\mathrm{H}_{0}: \beta_{0}=0 \text {; there is no impact of online } \\
\text { learning on students achievement } \\
\mathrm{H}_{1}: \beta_{0} \neq 0 \text {; } \begin{array}{c}
\text { there is impact of online } \\
\text { learningon students' } \\
\text { achievement }
\end{array}
\end{gathered}
$$

- Test Criteria:

Reject $\mathrm{H} 0$ and accept $\mathrm{H} 1$, if:

- $\quad$ Significance value $<\alpha=0.05$ 


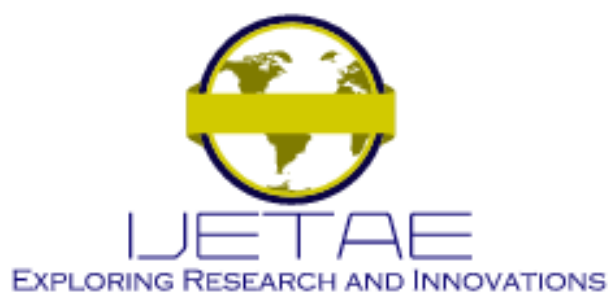

International Journal of Emerging Technology and Advanced Engineering Website: www.ijetae.com (E-ISSN 2250-2459, Scopus Indexed, ISO 9001:2008 Certified Journal, Volume 11, Issue 08, August 2021)

- f Table value:

$$
\begin{aligned}
& \mathrm{df}(\mathrm{n} 1)=\mathrm{k}-1, \text { therefore } 2-1=1 \\
& \mathrm{df}(\mathrm{n} 2)=\mathrm{n}-\mathrm{k}, \text { therefore } 35-2= \\
& 33 \text { Therefore, the value of } \mathrm{f} \text { Table } \\
& =4,14
\end{aligned}
$$

\begin{tabular}{|c|c|c|c|c|c|c|}
\hline \multicolumn{7}{|c|}{ ANOVA $^{\mathrm{a}}$} \\
\hline \multicolumn{2}{|c|}{ Model } & $\begin{array}{l}\text { Sum of } \\
\text { Squares }\end{array}$ & df & Mean Square & $\mathrm{F}$ & Sig. \\
\hline \multirow[t]{3}{*}{1} & Regression & 1388.184 & 1 & 1388.184 & 41.853 & $.000^{\mathrm{b}}$ \\
\hline & Residual & 1094.559 & 33 & 33.168 & & \\
\hline & Total & 2482.743 & 34 & & & \\
\hline \multicolumn{7}{|c|}{ a. Dependent Variable: Pelajar } \\
\hline \multicolumn{7}{|c|}{ b. Predictors: (Constant), PJJ } \\
\hline
\end{tabular}

Tabel 3

Coefficient

One of the factors that determine student success. In implementing Online Learning, mastery of technology is very important, as is the teaching method applied. The more effective the use of technology and teaching methods applied by the lecturer, the higher the learning motivation students will get.

We believe that the learning method that has been established during the current pandemic is a method of questionable effectiveness. The impact of the level of selfefficacy and student motivation is one proof, and if this continues, learning achievement will decrease.

It is the same if the lecturer who is responsible for an online class is not reliable in managing the continuity of his class. This of course will cause the classroom atmosphere to become saturated, and this is what reduces the level of student motivation. This is even more so if the learning material delivered is not carried out in a way that can attract students'attention.

Our doubts about the effectiveness of online learning are confirmed by this research we conducted. Although it is true that the existence of learning methods like this can help improve student scores on exams. But can their scores reallybe said to be an achievement? In our opinion, online learning activities should be reviewed by each school and their respective institutions, so that they can rearrange the learning method so that students can learn more comfortably.

\section{CONCLUSION}

Based on the data in Table 3, the significance value for Online Learning $(\mathrm{X})$ for Student's performance $(\mathrm{Y})$ is 0.00 $<0.05$ and the calculated $\mathrm{f}$ value $>$ the $\mathrm{f}$ table value, namely 41.853> 4.14. So, it can be concluded that $\mathrm{H}_{0}$ is rejected and $\mathrm{H}_{1}$ is accepted. In this case, it can be said that the Online Learning variable has a significant effect on the student performance variable. Thus, the Online Learning variable which contains indicators of learning activities, learning materials, and lecturers can be used to estimate and predict the student performance variables.

Perceptions of the effectiveness of Online Learning on Students performance according to the respondents obtained through the results of the questionnaire, show that Online Learning can be said to be not very effective. From the identification of problems that have been disclosed in the first chapter, from the results of the T-test and F-test, it was found that there was a significant influence between the Online Learning variable on students' performance. This means that the research hypothesis proposed by the author is accepted, namely that there is a negative and significant influence between the Online Learning variable on students' performance. So, it can be concluded that the learning methods applied by higher education institutions can have a considerable impact on the learning success of students and students' performance. From the learning activities that are applied, the learning material that is delivered and the lecturer who brings the material can have a significant impact and influence on student success. Therefore, the more effective the learning method is applied, the higher the learning motivation, learning achievement and self-efficacy that students will get. For the final statement of problem identification, the lecturer is also. The results of the validity test that have been conducted conclude that from variable $\mathrm{X}$, it is found that $\mathrm{KP} 2, \mathrm{PO} 3, \mathrm{PO} 4$ are considered invalid because they have a value below 0.3 . Meanwhile, for variable $\mathrm{Y}$, only one invalid was found, namely MB1. For reliability testing, where reliability is determined by Cronbach's alpha value, the variable research instrument has an alpha value of 0.909 .

The way to assess the variable research instrument is reliable or not is to compare the reliability statistics. Exceeding the value of 0.6, which is the minimum value of Cronbach's Alpha, it can be concluded that the variable research instrument is reliable. 


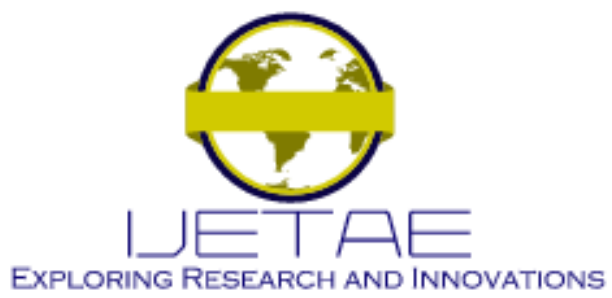

International Journal of Emerging Technology and Advanced Engineering

Website: www.ijetae.com (E-ISSN 2250-2459, Scopus Indexed, ISO 9001:2008 Certified Journal, Volume 11, Issue 08, August 2021)

However, if it is less than 0.6 , it can be concluded that the variable research instrument is not reliable.

To test the T-test hypothesis, the significance value of the influence of Online Learning (X) on Student's performance $(\mathrm{Y})$ concluded that there was a significant effect of Online Learning on Students performance. The way to determine it is by comparing the significance value (must be below 0.05) and comparing the calculated $\mathrm{T}$ value and $\mathrm{T}$ table. Then, the two numbers were compared. Meanwhile, for the F-test, it also concluded the same thing, where Online Learning has a significant influence on students' performance. How to determine it also is to compare the significance value and compare the calculated $\mathrm{F}$ value and $\mathrm{F}$ table. If $\mathrm{F}$ count is greater than the $\mathrm{Ftable}$ then $\mathrm{H} 0$ is rejected and $\mathrm{H} 1$ is accepted. From these tests, it can be concluded that Online Learning has a significant influence on students' performance.

\section{B. Implication}

From the research that has been done, it can be concluded that online learning that takes place can be said to be ineffective if it is carried out for a long time. Even so, this learning method can still be developed into a learning method that can be used in the future (such as 1-2 times a week for online learning) so that every student will not only learn from the higher education institution environment but can get useful knowledge during the time they spend outside of classes. The learning carried out outside of school can increase students' activity and creativity. Therefore, we must develop and continue this research and what activities are suitable for students and students so that they have a high enthusiasm for learning and have the drive or motivation to improve their learning achievement to be better than before.

\section{Suggestion}

Following are some suggestions that we wish to put forward, with the hope that these suggestions can help increase the effectiveness of implementing Online Learning to maximize the achievements that can be obtained by students:

1. The implementation of online learning should be monitored more closely, with higher emphasizing the rules for turning on the camera during the teaching and learning process. It would be even better if, during the class, the lecture is accompanied by a supervisor who can monitor the students. We suggest this to increase student learning motivation so that there is no significant decline.
2. Increase active interaction between lectures andstudents. Good communication between lectures and students can increase the seriousness in learning so that students do not feel bored during online learning. Moreover, if a lecture must have knowledge about students, learning in a class will take place more conducive. Therefore, we can interpret that teaching is an important factor in the success and achievement of a student.

\section{Limitations}

During the process of research, there were several obstacles that affected the process of research. The research was conducted during a pandemic, where the situation limits interactions between people and during the research process. The most significant obstacle is the Large-Scale Social Restrictions (PSBB). The entire research process, from start to finish was carried out separately and online. The greatest impact is on the collection of data from participants / respondents who are the focus of this research. The methods that can be selected for data collection are limited.

\section{Acknowledgment}

"This work is supported by Research and Technology Transfer Office, Bina Nusantara University as a part of Bina Nusantara University's International Research Grant entitled "Redesign Collaboration Tools For Productive Teamwork During Pandemic" with contract number: No: 017/VR.RTT/III/2021 and contract date: 22 Maret 2021."

\section{REFERENCES}

[1] A. A. T. Safaria, "Effects of self-efficacy on students' academic performance," J. Educ. Heal. Community Psychol., vol. 2, 2013.

[2] A. Wahyu and R. H. Simanullang, "Student Stress Due to Online Learning During the Covid-19 Pandemic," J. Aisyah J. Ilmu Kesehat., vol. 5, no. 2, 2020.

[3] Dpk, "Lecturer's union calls for better safety standards as schools reopen," The Jakarta Post, 2020.

[4] J. Németh and J. G. Long, "Assessing Learning Outcomes in U.S. Planning Studio Courses,” J. Plan. Educ. Res., 2012.

[5] Y. Pan, A. Olsson, and A. Golkar, "Social safety learning: Shared safety abolishes the recovery of learned threat," Behav. Res. Ther., vol. 135, no. June, p. 103733, 2020, doi: 10.1016/j.brat.2020.103733.

[6] R. R. V.Rasiah, "Transformative Higher Education Teaching and Learning: Using Social Media in a Team-based Learning Environment," in Procedia - Social and Behavioral Sciences, 2014, vol. 123, no. 2012, pp. 369-379, doi: 10.1016/j.sbspro.2014.01.1435. 


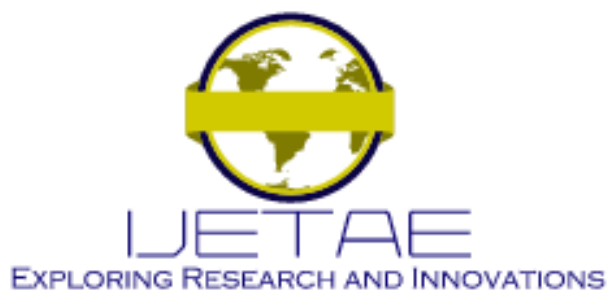

International Journal of Emerging Technology and Advanced Engineering

Website: www.ijetae.com (E-ISSN 2250-2459, Scopus Indexed, ISO 9001:2008 Certified Journal, Volume 11, Issue 08, August 2021)

[7] M. Paechter and B. Maier, "Online or face-to-face? Students' experiences and preferences in e-learning," Internet High. Educ., vol. 13, no. 4, pp. 292-297, 2010, doi: 10.1016/j.iheduc.2010.09.004.

[8] T. Oktavia, F. L. Gaol, T. Hosoda, and A. Syahir, "Transformative Sport Science Using Social Media as a Collaboration Tool,” 2020.
[9] N. Asvio, A. Arpinus, and S. Suharmon, "The Influence of Learning Motivation and Learning Environment on Undergraduate Student Learning Achievement of Management of Islamic Education, Study Program of Iain Batusangkar In 2016," Noble Int. J. Soc. Sci. Res., vol. 2, 2017.

[10] U. Tirtarahardja and L. S. S. L., Pengantar Pendidikan. Jakarta: Rineka Cipta, 2010. 